\title{
Estrogen Receptor $\beta$, but not $\alpha$, Mediates Estrogen's Effect on Cocaine-Induced Reinstatement of Extinguished Cocaine-Seeking Behavior in Ovariectomized Female Rats
}

\author{
Erin B Larson*,' and Marilyn E Carroll' \\ 'Department of Psychiatry, Graduate Program in Neuroscience, University of Minnesota, Minneapolis, MN, USA
}

\begin{abstract}
Preclinical and clinical studies indicate that females are more vulnerable to relapse than males, and the neurobiological effects of estrogen are thought to mediate, in part, the sex differences in cocaine-taking behavior. The goal of the present study was to investigate the involvement of estrogen receptor $\alpha(E R \alpha)$ and $\beta(E R \beta)$ in estrogen-mediated increases in cocaine-induced reinstatement of extinguished cocaine-seeking behavior in ovariectomized $(\mathrm{OVX})$ female rats. Rats were initially trained to self-administer cocaine $(0.4 \mathrm{mg} / \mathrm{kg} / \mathrm{inf}$, i.v.) under a fixed-ratio I (FR I) schedule of reinforcement during daily 2-h sessions. After a I0-day maintenance period, cocaine solutions were replaced with saline, and self-administration was extinguished over a 14 -day period. OVX rats were then treated with either the mixed ER $\alpha / \beta$ agonist estradiol benzoate (EB), the ER $\alpha$-selective agonist, propyl-pyrazole-triol (PPT), the ER $\beta$-selective agonist, diarylpropionitrile (DPN), or a vehicle control (dimethyl sulfoxide, DMSO). Treatment lasted a total of 9 days, and during this time, rats were assessed for nonreinforced reinstatement of extinguished cocaine-seeking behavior after priming injections of saline or cocaine (5, 10 , or $15 \mathrm{mg} / \mathrm{kg}$, i.p.). OVX rats showed no differences in self-administration during maintenance or extinction. OVX rats treated with EB exhibited greater responding for cocaine during reinstatement compared to OVX+DMSO controls. Selective activation of ER $\beta$ with DPN also increased cocaine-induced reinstatement responding, whereas selective activation of ER $\alpha$ with PPT did not affect cocaineseeking behavior. These results indicate that estrogen influences the propensity for reinstatement of extinguished cocaine-seeking behavior, and that estrogen-mediated enhancement of cocaine-induced reinstatement responding involves the activation of ER $\beta$. Neuropsychopharmacology (2007) 32, I334- 1345. doi: I0.1038/sj.npp. I 30 I249; published online 29 November 2006
\end{abstract}

Keywords: cocaine; estrogen; estrogen receptors; self-administration; reinstatement; relapse

\section{INTRODUCTION}

Studies in both humans and laboratory animals suggest that females are more vulnerable to drug abuse and addiction than males. It has been reported that females are more responsive than males to stimuli that cause relapse, including exposure to stress (Klein et al, 1997), drugs (Lynch and Carroll, 2000; Kippin et al, 2005), and drugassociated cues (Robbins et al, 1999; Elman et al, 2001, but see also Avants et al, 1995; Fuchs et al, 2005). Research on sex differences in the behavioral and neurochemical responses to drugs, particularly the stimulant drugs cocaine and amphetamine/methamphetamine, indicates that the gonadal hormone estrogen may be responsible for the

*Correspondence: Dr EB Larson, Department of Psychiatry, Graduate Program in Neuroscience, University of Minnesota, MMC 392, 420 Delaware St SE, Minneapolis, MN 55455, USA, Tel: + I 612624 4406, Fax: + I 612624 8935, E-mail: larso323@umn.edu

Received 30 March 2006; revised 8 August 2006; accepted 19 September 2006

Online publication: 3 October 2006 at http://www.acnp.org/citations/ Npp 10030606021 .pdf enhanced drug-induced responses in females compared to males (for review, see Becker, 1999; Festa and QuiñonesJenab, 2004). Self-administration studies suggest that estrogen also enhances drug reward and/or the motivation for drug-seeking behavior (for review, see Lynch et al, 2002; Carroll et al, 2004; Roth et al, 2004). For example, it has been shown that removal of endogenous estrogen by ovariectomy (OVX) decreases acquisition of cocaine selfadministration (Lynch et al, 2001) and cocaine-primed reinstatement of extinguished cocaine-seeking behavior in rats (Larson et al, 2005). Conversely, exogenous estrogen administration in OVX rats increases acquisition of cocaine self-administration (Lynch et al, 2001; Hu et al, 2004; Jackson et al, 2006) and cocaine-induced reinstatement of cocaine-seeking behavior (Larson et al, 2005).

Given the high rates of relapse to cocaine use, and the finding that females may be more likely than males to relapse, it is important to understand the mechanisms underlying estrogen's effects on cocaine-seeking behavior. Estrogen is known to produce many of its effects by acting at its major estrogen receptor (ER) subtypes, $\mathrm{ER} \alpha$ and $\mathrm{ER} \beta$. Both $\operatorname{ER} \alpha$ and $\operatorname{ER} \beta$ are highly expressed in the central 
nervous system, particularly in the brain in limbicassociated structures such as the amygdala, the hypothalamus, and the bed nucleus of stria terminalis. However, the concentration and distribution of each receptor subtype within as well as outside these regions can vary greatly (Laflamme et al, 1998, reviewed by McEwen and Alves, 1999). It has been reported that $\operatorname{ER} \beta$ mRNA exists in brain regions where there is little or no $\mathrm{ER} \alpha$ (eg, isocortex, cerebellum, ventral tegmental area (VTA)), and ER $\alpha$ can be found in other regions (eg, periaquaductal grey, arcuate nucleus, subfornical organ) that have little or no $\operatorname{ER} \beta$ (Kuiper et al, 1997; Shughrue et al, 1997; Laflamme et al, 1998). However, it should be noted that the relative abundance of $\operatorname{ER} \alpha$ and $\operatorname{ER} \beta$ found in various brain regions can be ambiguous. For example, whereas a predominance of $\mathrm{ER} \beta$ mRNA has been consistently reported throughout the isocortex (Laflamme et al, 1998; Shughrue et al, 1997), there is conflict regarding which ER subtype predominates in the allocortex (Laflamme et al, 1998; Shughrue et al, 1997). Similarly, variable results have been found regarding ER localization in the substantia nigra, with some investigators finding more $\mathrm{ER} \alpha$ than $\mathrm{ER} \beta$ mRNA in the pars compacta (Laflamme et al, 1998), and others reporting only weak staining for $\operatorname{ER} \beta$ mRNA in this region (Shughrue et al, 1997).

In some brain areas such as the striatum, estrogen effects are well documented (for review, see Becker 1999); however, the existence of either receptor subtype in these areas is controversial (Pfaff and Keiner, 1973; Roy et al, 1990; Shughrue et al, 1997; Kuppers and Beyer, 1999). For example, one study found no $\operatorname{ER} \alpha$ or $\operatorname{ER} \beta$ mRNA in the striatum of adult male and female rats (Laflamme et al, 1998), whereas another study found both $\operatorname{ER} \alpha$ and $\operatorname{ER} \beta$ mRNA in the striatum of adult mice (Kuppers and Beyer, 1999). Also, in the nucleus accumbens (ventral striatum) of adult rats, $\mathrm{ER} \beta$ mRNA labeling has been reported (Shughrue et al, 1997), but only minimal levels of $\operatorname{ER} \beta$ protein have been found (Shughrue and Merchenthaler, 2001). Nevertheless, given the important role estrogen seems to play in drug abuse and the finding that ERs exist in many of the brain regions implicated in the rewarding and motivational aspects of drugs of abuse (eg, VTA, amygdala, nucleus accumbens, and cortex), further investigation of the role of $\operatorname{ER} \alpha$ and $\operatorname{ER} \beta$ on cocaine-seeking behavior in rats in warranted.

In order to better understand the functions of $\mathrm{ER} \alpha$ and $\mathrm{ER} \beta$, researchers have typically taken advantage of the availability of ER selective knockouts (ERKOs) and selective ER modulators (SERMs) such as ER selective agonists (Stauffer et al, 2000; Meyers et al, 2001) and antagonists (Barkhem et al, 1998; Hall et al, 2000; Sun et al, 2005). Use of these techniques have helped to identify the involvement of $\mathrm{ER} \alpha$ and/or $\mathrm{ER} \beta$ in several biological functions, including mating and reproduction (Ogawa et al, 1998, 1999; Hewitt and Korach, 2003), anxiety (Krezel et al, 2001; Walf and Frye, 2005; Imwalle et al, 2005; Lund et al, 2005), learning and memory (Fugger et al, 2000; Rissman et al, 2002), wheel running (Ogawa et al, 2003), and food intake (Geary et al, 2001; Roesch, 2006). For example, ERKO studies in mice have shown that $E R \alpha$ is required for normal sexual receptivity and fertility in mice and rats, whereas $\operatorname{ER} \beta$ does not appear to be critical for reproductive function (Hewitt and Korach, 2003). Studies in rats using SERMs have demonstrated that activation of $\operatorname{ER} \beta$ increases, whereas activation of $\mathrm{ER} \alpha$ decreases or has no effect on, the number of entries or time spent in the open arms of an elevated plus maze, indicating that $\operatorname{ER} \beta$ mediates the anxiolytic effects of estrogen (Lund et al, 2005; Walf and Frye, 2005). Furthermore, studies using both techniques have suggested that $\operatorname{ER} \alpha$ and $\operatorname{ER} \beta$ may both be important for hippocampaldependent learning and memory, although results can vary depending on the task (eg, inhibitory avoidance and spatial learning, and so on) being measured (Fugger et al, 2000; Rissman et al, 2002).

Although several studies have examined estrogenmediated effects on cocaine-mediated responses (Lynch et al, 2002; Festa and Quiñones-Jenab, 2004; Roth et al, 2004), including the reinstatement of cocaine-seeking behavior after an abstinence period (Fuchs et al, 2005; Larson et al, 2005; Kippin et al, 2005), no studies to date have investigated the role of $\operatorname{ER} \alpha$ and $\operatorname{ER} \beta$ in these effects. Therefore, the goal of the present study was use ER selective agonists to identify the involvement of $\operatorname{ER} \alpha$ and $\operatorname{ER} \beta$ in estrogen's ability to enhance reinstatement of cocaineseeking behavior in female OVX rats. Four groups of OVX rats were initially allowed to self-administer cocaine by lever-press, and they were subsequently exposed to 14 days of extinction (abstinence). At the end of the extinction phase, each group received one of the following treatments: (1) $17-\beta$ estradiol benzoate (EB), a mixed ER $\alpha / \beta$ agonist, (2) propyl-pyrazole-triol (PPT), a selective $\mathrm{ER} \alpha$ agonist with a 410 -fold selectivity for $\operatorname{ER} \alpha$ over $\operatorname{ER} \beta$ (Stauffer et al, 2000), (3) diarylpropionitrile (DPN), a selective $\operatorname{ER} \beta$ agonist with a 70 -fold selectivity for $\operatorname{ER} \beta$ over $\operatorname{ER} \alpha$ (Meyers et al, 2001), or (4) the vehicle, dimethyl sulfoxide (DMSO, control). Three days after the start of treatment, rats were exposed to a reinstatement protocol in which saline or cocaine priming injections were given in an alternating manner, and responding on the previously active (cocaine paired) and inactive (not cocaine paired) levers was measured, but not reinforced. Reinstatement of responding on the previously active lever was considered an indicator of cocaine-seeking behavior, and responding was compared between groups across a range of cocaine doses.

\section{MATERIALS AND METHODS}

\section{Subjects}

A total of 41 experimentally naïve, adult (mean age at surgery: $86.2 \pm 2.78$ days) female Wistar rats were used as subjects in this study ( $n=10-11$ per group). Rats were obtained from Harlan Sprague-Dawley (Madison, WI) and they were pair-housed in plastic holding cages before surgery. During this time, rats were given ad libitum access to food (pellet chow, Purina Mills, Minneapolis, MN) and water. After surgery, they were individually housed in their experimental chambers, where they remained for the duration of the experiment. Intake of food (ground pellet chow, Purina Mills, Minneapolis, MN) and water were measured every morning $(0800-0900 \mathrm{~h})$. Each group of rats was fed a fixed amount of food $(16 \mathrm{~g})$ every afternoon $(1500 \mathrm{~h})$ to equalize food intake. All laboratory rooms where rats were housed were kept under controlled temperature 
$\left(21-23^{\circ} \mathrm{C}\right)$, humidity, and light $(12 / 12$ light/dark cycle, lights on at 0600) conditions. The University of Minnesota Institutional Care and Use Committee (IACUC) approved the experimental protocol under protocol number 0410A64760, and experimental procedures conformed to the Principles of Laboratory Animal Care (National Research Council, 2003). The Association for Assessment and Accreditation of Laboratory Animal Care (AAALAC) approved and accredited all laboratory facilities.

\section{Drugs}

Cocaine (NIDA, Research Triangle Park, NC) was dissolved in a sterile $0.9 \%$ saline solution containing heparin (5 USP U/ml). Cocaine stock solutions were made every 2 weeks, and they were kept refrigerated before use, at which time they were added to syringe pumps (for self-administration) or $1 \mathrm{ml}$ syringes (for reinstatement testing) that were then brought to room temperature. The cocaine solution $(1.6 \mathrm{mg} / \mathrm{ml})$ that was used for self-administration $(0.4 \mathrm{mg} / \mathrm{kg} /$ inf, i.v.) was delivered at a rate of $0.025 \mathrm{ml} / \mathrm{s}$ and a duration of $1 \mathrm{~s} / 100 \mathrm{~g}$ body weight. For reinstatement, cocaine $(8.0 \mathrm{mg} /$ $\mathrm{ml}$ ) or saline vehicle was prepared such that each rat received the same injection volume on each testing day regardless of the cocaine dose $(0,5,10$, or $15 \mathrm{mg} / \mathrm{kg}$, i.p.). The DMSO vehicle and EB were purchased from SigmaAldrich (St Louis, MO), and PPT and DPN were obtained from Tocris Bioscience (Ellisville, MO). All treatment drugs were dissolved in DMSO, and the concentrations for all estrogen agonist treatments $(1.0 \mathrm{mg} / \mathrm{ml} \mathrm{EB}, 1.0 \mathrm{mg} / \mathrm{ml} \mathrm{PPT}$, and $1.0 \mathrm{mg} / \mathrm{ml} \mathrm{DPN}$ ) were prepared so that each rat received similar injection volumes during treatment. The dose of EB $(0.05 \mathrm{mg} / \mathrm{kg} / \mathrm{inj}$, subcutaneously (s.c.)) was based on what has been previously shown to enhance cocaine-induced reinstatement of lever responding in OVX rats (Larson et al, 2005). The doses of PPT $(1.0 \mathrm{mg} / \mathrm{kg} / \mathrm{inj}$, i.p.) and DPN $(1.0 \mathrm{mg} / \mathrm{kg} / \mathrm{inj}$, i.p.) correspond to effective doses that have been previously reported (Harris et al, 2002; Frasor et al, 2003; Lund et al, 2005; Le Saux and Di Paolo, 2005; Le Saux et al, 2006). These previous reports indicate that, in some cases, selective activation of ER $\alpha$ or ER $\beta$ by a $1.0 \mathrm{mg} / \mathrm{kg}$ dose of PPT $(\mathrm{ER} \alpha)$ or DPN (ER $\beta)$ produced similar effects, such as in the striatum, where both increased preproenkephalin mRNA levels (Le Saux and Di Paolo, 2005). Other times, selective activation of $\operatorname{ER} \alpha$ and $\operatorname{ER} \beta$ had opposing effects. For example, a $1.0 \mathrm{mg} / \mathrm{kg}$ dose of PPT decreased the time spent in the open arms of an elevated plus maze, whereas the same dose of DPN increased it compared to controls, suggesting opposing influences of $\operatorname{ER} \alpha$ and $\operatorname{ER} \beta$ on anxiety behavior (Lund et al, 2005). In other cases, only activation of one of the ER subtypes had an effect, as shown by the ability of a $1.0 \mathrm{mg} / \mathrm{kg}$ dose of DPN, but not PPT, to increase $\mathrm{D}_{2}$ receptor levels in the striatum and nucleus accumbens (Le Saux et al, 2006).

\section{Apparatus}

Custom-made operant chambers were used for housing rats after surgery, and rats lived in these chambers for the duration of the experiment. Chambers were octagonal in shape and had alternating stainless steel and Plexiglas walls. The stainless steel walls contained inserts for the food hopper, drinking spout, a house light, two response levers, and two stimulus light panels (Coulbourn Instruments, Lehigh Valley, PA). The house light $(4.76 \mathrm{~W})$ was located at the top of the chamber. The food and water inserts were positioned on the two panels opposite the response levers. A stimulus light panel was placed directly above each response lever, and each panel consisted of three colored LED lights $(4.76 \mathrm{~W})$, that were simultaneously illuminated upon a lever press. All operant chambers were enclosed in custom-made, sound-attenuating melamine-coated wooden boxes containing a fan that provided ventilation and white noise. Each cocaine infusion system consisted of a syringe pump (model PHM-100, Med Associates, St Albans, VT) with a $30 \mathrm{ml}$ syringe that was connected to a blunted 22 gauge needle tip and attached to Tygon tubing $(1.52 \mathrm{~mm}$ o.d., $0.51 \mathrm{~mm}$ i.d., Fisher Scientific, Springfield, NJ). The free end of the tubing was connected to a swivel (050-0022, Alice King Chatham, Hawthorne, CA) that was mounted at the top center of the operant chamber. The swivel was secured to a spring-covered tether (C313CS, Plastic Products, Roanoke, VA) that extended down into the operant chamber and was attached to the rats covance infusion harness (Instech Laboratories, Plymouth Meeting, PA). IBM-compatible computers equipped with a Med-PC interface (Med Associates, St Albans, VT) were used for programming, data collection, and data storage during all experimental sessions.

\section{Procedure}

Surgery. Aseptic techniques were used for all surgical procedures. Rats were anesthetized with ketamine $(60 \mathrm{mg} /$ $\mathrm{kg}$, i.p.) and xylazine $(10 \mathrm{mg} / \mathrm{kg}$, i.p.). Rats were supplemented with doxapram $(5 \mathrm{mg} / \mathrm{kg}$, s.c.) to stimulate/stabilize respiration, and atropine $(0.4 \mathrm{mg} / \mathrm{ml}, 0.15 \mathrm{ml}$, s.c.) was given to prevent bradycardia and to reduce pharyngeal and tracheal secretions (eg, mucus) that are normally removed by a swallowing reflex in a nonanesthetized animal. Once anesthetized, rats received a bilateral OVX and their right jugular vein was cathetherized to allow for i.v. cocaine selfadministration. For catheterization, an incision was made ventrally at an area rostral to the thorax and lateral to the trachea, and connective tissues were separated with hemostats to allow for isolation of the right jugular vein. The tapered end of a chronic, indwelling silastic catheter that had been previously disinfected in betadine was then inserted into the vein and secured with silk suture. The free end of the catheter was tunneled s.c., exited in the midscapular region, and attached to a cannula (C3236, Plastic One, Roanoke, VA) incorporated in a covance harness that was secured onto the rat. The free end of this cannula was capped until the following day, when it was attached the tether/swivel attachment. For the OVX surgery, a bilateral incision of the dorsal abdomen was made with a scalpel, and muscle wall was separated with hemostats to allow access to the abdominal cavity. Hemostats were used to localize the ovaries, which were gently externalized and separated from the surrounding adipose tissue before being removed with a scalpel. The remaining fallopian tubes were clamped until any bleeding had ceased, the area was rinsed with sterile saline, and tissues were then returned to the abdominal cavity. For both surgeries, previously separated 
muscle wall and outer incisions were sutured with chromic gut (Ethicon Inc., Somerville, NJ), and povidine was applied to outer incisions to prevent infection.

Rats were given a total of 10 days to recover from surgery. After recovery from anesthesia, buprenorphine $(0.5 \mathrm{mg} / \mathrm{kg}$, s.c., b.i.d.) was given for 2 days as a postoperative analgesic. During this time, rats were also given the antibiotic gentamicin $(2 \mathrm{mg} / \mathrm{kg}$, i.v.) and heparinized saline (50 USP U/ml, $0.3 \mathrm{ml} / \mathrm{rat})$. Heparinized saline $(0.3 \mathrm{ml} / \mathrm{rat} /$ day $)$ was also given for the following week of recovery to reduce blood clotting in the catheter. After recovery, syringe pump tubing was connected to the free (capped) end of the tether/ swivel assembly, and experimental sessions commenced. During the experiment, rats were weighed every week, and catheter patency was assessed by injecting (i.v.) a combination of ketamine $(100 \mathrm{mg} / \mathrm{ml})$, midazolam $(5 \mathrm{mg} / \mathrm{ml})$, and saline $(3: 3: 14$ ratio, $0.10-0.20 \mathrm{ml} / \mathrm{rat})$. If this drug combination produced an immediate loss of the righting reflex upon administration, the catheter was considered to be patent. If not, the experimental session was terminated, the rat was implanted with a new catheter into its left jugular vein, allowed to recover for 3 days, and it was then returned to the experiment.

Training. After recovery from surgery, rats were initially trained to lever-press for cocaine reinforcement. Cocaine self-administration training consisted of a fixed-ratio (FR 1) schedule of reinforcement $(0.4 \mathrm{mg} / \mathrm{kg} / \mathrm{inf}$, i.v.) and took place in daily, 6-h sessions starting at $0900 \mathrm{~h}$. Training sessions were initiated by the illumination of the house light and the noncontingent administration of two cocaine infusions. Responding on either the active (drug) or the inactive (control) lever resulted in illumination of the corresponding stimulus lights above the lever, but only a response on the active lever resulted in a drug infusion. If rats responded on the active lever $\geqslant 75$ times/day for 3 days, and had active:inactive lever-press ratios of at least $2: 1$, their priming infusions were discontinued. If, on the following day, rats continued to respond ( $\geqslant 50$ responses), they progressed into the maintenance phase of the experiment. If they did not continue to respond, their priming infusions were reinstated, and they were subsequently weaned off priming injections until they met the above stated criteria.

Maintenance. For maintenance, self-administration sessions were limited to 2-h/day (starting at $0900 \mathrm{~h}$ ), and rats were allowed to self-administer cocaine $(0.4 \mathrm{mg} / \mathrm{kg} / \mathrm{inf}$, i.v.) for 10 days under a FR 1 schedule. Similar to training, the onset of maintenance sessions were signaled by the house light, and lever pressing during the session was accompanied by stimulus light illumination. However, in contrast to training, no priming infusions were given during maintenance. Rats were assigned to treatment groups following maintenance, and groups were matched for cocaine intake to control for potential differences in cocaine-seeking during reinstatement testing that could be related to prior cocaine intake levels (Sutton et al, 2000).

Extinction. After maintenance, saline solutions containing heparin (50 USP U/ml) were substituted in place of the cocaine solutions, and rats were allowed to self-administer saline during 14 daily 2-h sessions (0900-1100 h), under FR 1 conditions. All other stimulus conditions (ie, house light onset, stimulus light illumination) remained the same as during the maintenance phase. Under these abstinence conditions, responding decreases gradually, and it typically reaches minimal levels in 8-10 days (Larson and Carroll, 2005; Larson et al, 2005; Perry et al, 2006).

Pre-reinstatement. At the end of the extinction phase, saline pumps were disconnected from the swivel/tether assembly, and the house light and stimulus lights were turned off. Thus, lever pressing by the rats was without consequence. This phase was included to ensure that responding during reinstatement testing was specifically in response to priming injections (saline or cocaine) and was not influenced by cues (ie, house light, stimulus light, or interoceptive cues from an i.v. infusion). This was carried out because previous studies have demonstrated that exposure to compound stimuli can increase reinstatement responding compared to exposure to a single stimulus, and this can occur even if responding to one of the stimuli (eg, cue light) has previously been extinguished (See et al, 1999; Shelton and Beardsley, 2005).

Reinstatement. Reinstatement testing consisted of 6 daily 2 -h sessions that began at 0900 with the noncontingent administration of either a saline (S) or a cocaine (C) priming injection (i.p.). Testing progressed over the 6 days according to the following sequence: S C S C S C. The number of responses on the previously active and inactive levers was counted during each session, but there were no programmed consequences associated with lever pressing. In order to assess dose-response functions, cocainemediated reinstatement of active lever responding was assessed after the administration of three different doses of cocaine $(5,10$, or $15 \mathrm{mg} / \mathrm{kg}$, i.p.). Cocaine dose order was randomly assigned in each rat, and one of the three cocaine doses was assessed on each cocaine testing day, preceded and separated by a day when an i.p. saline priming injection was given.

Hormone treatment. After completion of the maintenance phase, rats were assigned to one of the following treatment groups: (1) OVX + EB $(\mathrm{ER} \alpha / \beta, n=10)$, (2) OVX + PPT (ER $\alpha$, $n=11)$, (3) OVX + DPN (ER $\beta, n=10)$, or (4) OVX + DMSO (control, $n=10)$. Groups were matched according to their cocaine self-administration during maintenance, so that differences in responding during reinstatement could be directly attributed to treatment and not to differences in drug intake during maintenance. Treatment with DMSO, $\mathrm{EB}, \mathrm{PPT}$, or DPN began on the first day of pre-reinstatement; thus, rats were OVX for an average ( \pm SEM) of 47.07 $( \pm 1.44)$ days prior treatment. All treatments were administered at 0830 on each day of testing, and treatment lasted a total of 9 days, with the final injection being given on the last day of reinstatement testing. The duration of hormone treatment used in this study was chosen based on a previous study (Larson et al, 2005) indicating that 9 days of EB treatment enhanced the magnitude of cocaine-induced reinstatement responding in OVX female rats. 
To confirm the appropriate hormonal condition in each rat, vaginal cytology was assessed at two time points in this experiment. During these time points, vaginal samples were taken at $1400 \mathrm{~h}$ each day, transferred to slides, stained with methylene blue, and cover slipped. The first set of samples was taken during recovery from surgery, for 5 days before the initiation of cocaine self-administration training. This was carried out in order to verify completeness of the OVX surgery and dissipation of endogenous hormones, as indicated by the predominance of leukocytes and/or the absence of epithelial cells in the samples. Only rats that had slides that verified a complete OVX were used in the study. After obtaining the first set of samples, swabbing was discontinued, and it resumed during hormonal treatment, which occurred during the pre-reinstatement and reinstatement phases of the experiment (9 days total). This second set of samples was taken in order to confirm that the rats' hormonal status was consistent with its treatment group. For example, OVX rats treated with DMSO (control) had cytology similar to untreated OVX rats (predominance of leukocytes), rats treated with EB $(\mathrm{ER} \alpha / \beta)$ had cytology showing a predominance of cornified epithelial cells, rats treated with PPT (ER $\alpha$ ) had samples that consisted mainly of nucleated and/or cornified epithelial cells, and rats treated with DPN (ER $\beta)$ had slides similar to untreated OVX rats, although the presence of polymorphic epithelial cells was also noted in these animals.

Data analyses. All statistical analyses were conducted using GB Stat (Dynamic Microsystems Inc., Silver Spring, MD). Dependent measures were the number of infusions selfadministered during maintenance and extinction, and the number of responses made during reinstatement. The number of cocaine infusions self-administered across the 10-day maintenance phase was analyzed with a two-way repeated measure analysis of variance (ANOVA), with group as the between-subject factor, and maintenance day as the within-subject, repeated factor. The number of saline infusions self-administered across the 14-day extinction phase was also analyzed using a two-way repeated measure ANOVA, with the same between- and within-group factors (ie, group and day). The number of active and inactive lever responses made during reinstatement was analyzed separately using two-way repeated measure ANOVAs, with treatment as the between-group factor and dose as the within-group, repeated factor. When appropriate, post hoc tests were conducted using Fisher's LSD protected $t$-tests. Results were considered significant if $p<0.05$.

\section{RESULTS}

\section{Training}

A total of 62 OVX female rats underwent training for cocaine self-administration. Of these, a total of 41 rats (66\%) reached the training criteria, and those that did so reached the criteria in an average $( \pm$ SEM $)$ of $13.07( \pm 1.44)$ days. These rats were then allowed to self-administer cocaine across a 10-day maintenance period, and they were separated into treatment groups so that each group had similar cocaine self-administration histories before treatment and reinstatement testing. Retrospective analysis indicated that matching groups based on their cocaine self-administration during maintenance resulted in four groups of OVX rats that did not differ in their time to reach the training criteria for cocaine self-administration (Figure 1). The average ( \pm SEM) number of days needed to reach the training criteria was $14.8( \pm 3.28), 10.5( \pm 1.72)$, $10.73( \pm 2.93)$, and $16.5( \pm 3.50)$ days for OVX + DMSO (control), OVX + EB $(\mathrm{ER} \alpha / \beta)$, OVX + PPT $(\mathrm{ER} \alpha)$, and OVX + DPN $(\mathrm{ER} \beta)$ groups, respectively.

\section{Maintenance and Extinction}

As depicted in Figure 2, matching OVX rats according to their self-administration behavior during maintenance resulted in four groups that showed no significant differences in cocaine self-administration as a function of group $(p>0.05)$ or day $(p>0.05)$. The rats in the OVX

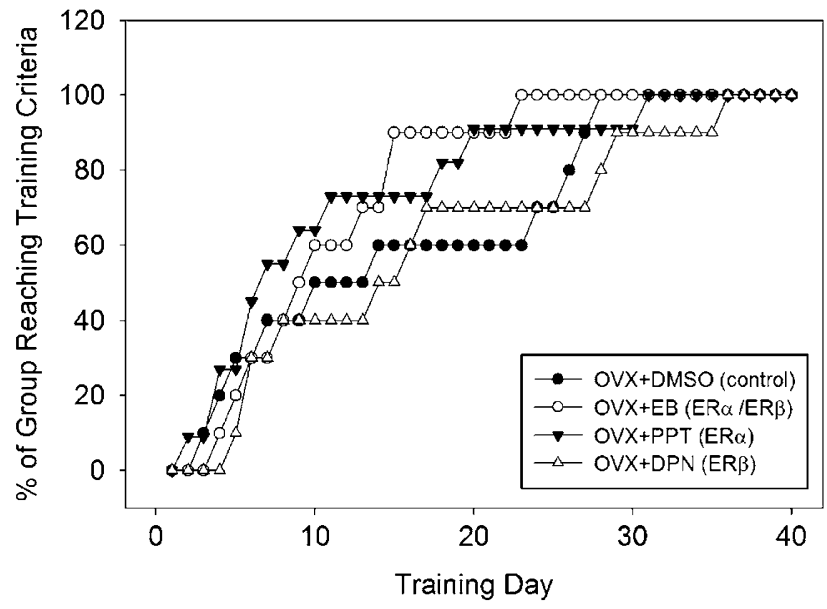

Figure I Training. The percent of rats that had reached the training criteria for cocaine self-administration are depicted across training days. The number of days needed to reach the training criteria did not differ between the four groups of OVX rats.

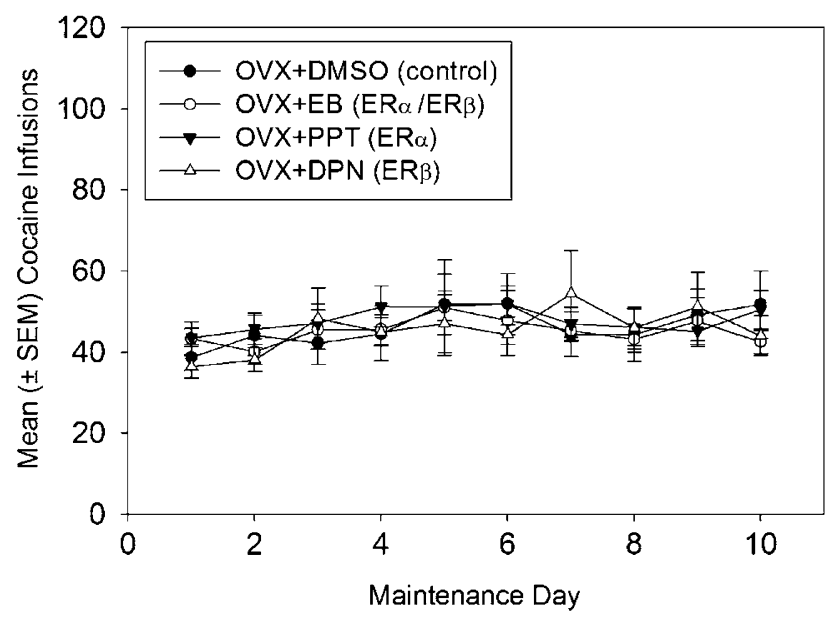

Figure 2 Maintenance. Data points represent the mean $( \pm S E M)$ number of cocaine infusions $(0.4 \mathrm{mg} / \mathrm{kg} / \mathrm{inf})$ self-administered by female OVX rats during 2-h sessions across the 10-day maintenance period. Groups were matched for similar cocaine self-administration in this phase. 
+ DMSO (control), OVX + EB $(\mathrm{ER} \alpha / \beta), \mathrm{OVX}+\mathrm{PPT}(\mathrm{ER} \alpha)$, and OVX + DPN $(\mathrm{ER} \beta)$ groups self-administered an average $( \pm$ SEM) of $46.3( \pm 4.7), 45.1( \pm 3.0), 47.9( \pm 3.0)$, and 45.2 $( \pm 2.3)$ infusions per day over the 10-day maintenance period. In all groups, the number of cocaine infusions selfadministered from day-to-day remained relatively stable across the maintenance period.

As Figure 3 illustrates, group matching for cocaine intake during maintenance also resulted in four groups of rats that had similar levels of saline self-administration during extinction $(p>0.05)$. There was no difference in how long it took rats to extinguish cocaine-seeking behavior. In all groups of rats, saline replacement led to responding that decreased as a function of extinction day $\left(\mathrm{F}_{13,573}=26.094\right.$, $p<0.0001$ ), and responding reached asymptotic low levels by extinction days 8-9.

Table 1 indicates that the number of responses made on the inactive lever during maintenance and extinction was low relative to those made on the active lever during both maintenance $\left(\mathrm{F}_{1,87}=188.489, p<0.0001\right)$ and extinction $\left(\mathrm{F}_{1,87}=188.489, p<0.0001\right)$. Post hoc comparisons revealed that this difference was found in all groups $\left({ }^{*} p<0.05\right.$, Table 1). Similar to what was found for the number of infusions self-administered, there were no group differences in the number of responses made on the active lever during maintenance or extinction. There were also no differences in inactive lever responding during this time.

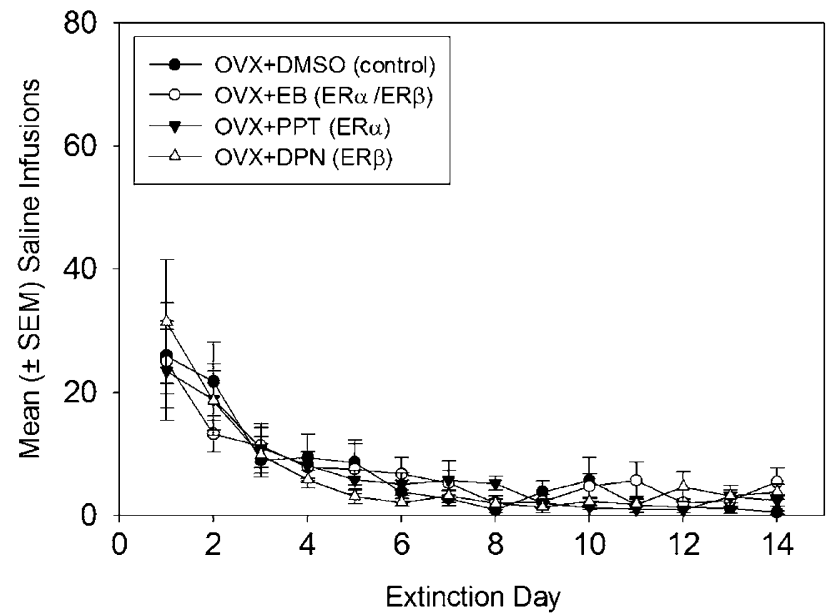

Figure 3 Extinction. Data points represent the mean ( \pm SEM) number of saline infusions self-administered by female OVX rats during 2-h sessions across the 14-day extinction period.

\section{Pre-reinstatement and Reinstatement}

During the 3-day pre-reinstatement period, there were no significant within- or between-group differences in the number of responses made on either the active or the inactive levers (Table 1). Responding on both the previously active and inactive levers was low during this time, and it was comparable to what was found at the end of the extinction phase. During reinstatement testing, there were no differences in responding on the previously active (cocaine paired) lever across days where saline priming injections were given; therefore, data from saline testing days were collapsed within groups. Figure 4 illustrates that, in all groups of rats, responding on the previously active lever was low after saline priming ( $0 \mathrm{mg} / \mathrm{kg}$ cocaine), and it was comparable to the number of responses made during the pre-reinstatement phase. In contrast, exposure to cocaine priming injections dose dependently increased the number of times the rats responded on the previously active lever $\left(\mathrm{F}_{3,163}=21.110, p<0.0001\right)$. The amount of active lever responding after cocaine priming injections also differed as a function of treatment group $\left(\mathrm{F}_{3,163}=3.158, p=0.036\right)$. Post hoc analyses revealed that there were group differences in the lowest dose of cocaine needed to reinstate active lever responding. Both the OVX $+\mathrm{EB}(\mathrm{ER} \alpha / \beta)$ and $\mathrm{OVX}+\mathrm{DPN}$

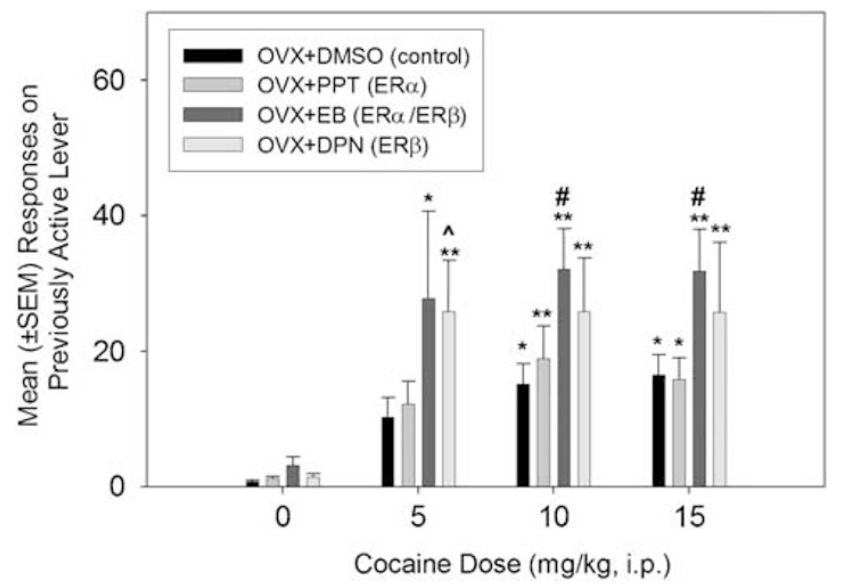

Figure 4 Reinstatement-active lever responding. Data points represent the mean $( \pm S E M)$ number of responses on the previously active (cocaine paired) lever. $* p<0.05$, $* * * 0.01$ compared to $0 \mathrm{mg} / \mathrm{kg}$ dose within group, ${ }^{\#} p<0.05 \mathrm{OVX}+\mathrm{EB}$ compared to OVX+DMSO and OVX + PPT groups, ${ }^{\wedge} p<0.05 \mathrm{OVX}+\mathrm{DPN}$ compared to OVX+DMSO and OVX +PPT groups.

Table I Mean ( \pm SEM) Responses on Active and Inactive Levers

\begin{tabular}{|c|c|c|c|c|c|c|c|c|}
\hline & \multicolumn{2}{|c|}{ OVX+DMSO } & \multicolumn{2}{|c|}{ OVX+EB } & \multicolumn{2}{|c|}{ OVX+PPT } & \multicolumn{2}{|c|}{ OVX+DPN } \\
\hline & Active & Inactive & Active & Inactive & Active & Inactive & Active & Inactive \\
\hline Extinction & $9.41( \pm 2.5)^{*}$ & $2.62( \pm 1.1)$ & $|0.2|( \pm 2.2)^{*}$ & $3.80( \pm 1.2)$ & $8.36( \pm 2.1)^{*}$ & $3.03( \pm 0.8)$ & $8.02( \pm 1.6)^{*}$ & $1.88( \pm 0.5)$ \\
\hline Pre-reinstatement & $1.07( \pm 0.4)$ & $1.22( \pm 1.1)$ & $2.60( \pm 0.9)$ & $1.54( \pm 0.7)$ & $1.85( \pm 0.6)$ & $1.03( \pm 0.3)$ & $1.47( \pm 0.5)$ & $1.38( \pm 0.4)$ \\
\hline
\end{tabular}

$* p<0.05$ active vs inactive lever responding, within group and phase. 
$(\mathrm{ER} \beta)$ groups had significant increases in active lever responding after the $5 \mathrm{mg} / \mathrm{kg}$ cocaine prime, whereas at least $10 \mathrm{mg} / \mathrm{kg}$ cocaine was needed to produce significant increases in active lever responding in the OVX $+\mathrm{DMSO}$ (control) and OVX $+\mathrm{PPT}(\mathrm{ER} \alpha)$ groups $\left({ }^{*} p<0.05\right.$, ${ }^{*} p<0.01$ vs $0 \mathrm{mg} / \mathrm{kg}$ dose, Figure 4). Post hoc comparisons also revealed group differences in the magnitude of active lever responding after cocaine priming injections. The OVX + EB group had more active lever responding after the 10 and $15 \mathrm{mg} / \mathrm{kg}$ doses of cocaine when compared to either the OVX + DMSO or OVX + PPT groups $\left({ }^{\#} p<0.05\right.$, Figure 4$)$, and OVX + DPN group had higher active lever responding compared to the OVX + DMSO and OVX + PPT groups after $5 \mathrm{mg} / \mathrm{kg}$ cocaine $(\wedge p<0.05$, Figure 4$)$.

Figure 5 depicts the number of responses made on the previously inactive (not cocaine-paired) lever during reinstatement testing after rats were exposure to the saline or cocaine priming injections. Analysis revealed that, similar to active lever responding, responding on the inactive lever increased as a function of cocaine dose $\left(F_{3,163}=9.068, p<0.0001\right)$. Post hoc analyses indicated that inactive lever responding was increased after priming with the 5,10 , and $15 \mathrm{mg} / \mathrm{kg}$ doses of cocaine in OVX $+\mathrm{EB}(\mathrm{ER} \alpha /$ $\beta$ ) rats, and in response to the $15 \mathrm{mg} / \mathrm{kg}$ cocaine priming dose in OVX $+\mathrm{PPT}(\mathrm{ER} \alpha)$ rats $\left({ }^{*} p<0.05,{ }^{* *} p<0.01\right.$ vs $0 \mathrm{mg} /$ $\mathrm{kg}$ dose, Figure 5). The amount of inactive lever responding after cocaine also differed between groups $\left(\mathrm{F}_{1,163}=3.823\right.$, $p=0.0176)$. The cocaine-induced increase in inactive lever responding after the $15 \mathrm{mg} / \mathrm{kg}$ cocaine prime was higher in the OVX +EB group compared to both OVX +DMSO (control) and OVX + DPN $(\operatorname{ER} \beta)$ groups $\left({ }^{\#} p<0.05\right.$, Figure 5$)$. Similarly, the OVX + PPT group made more inactive lever responses after the $15 \mathrm{mg} / \mathrm{kg}$ cocaine prime than either the OVX + DMSO and OVX + DPN groups ( $p<0.05$, Figure 5).

Given that cocaine led to increases in both active and inactive lever responding in $\mathrm{OVX}+\mathrm{EB}(\mathrm{ER} \alpha / \beta)$ rats, an additional analysis was conducted to determine whether there were differences in the magnitude of cocaine-induced

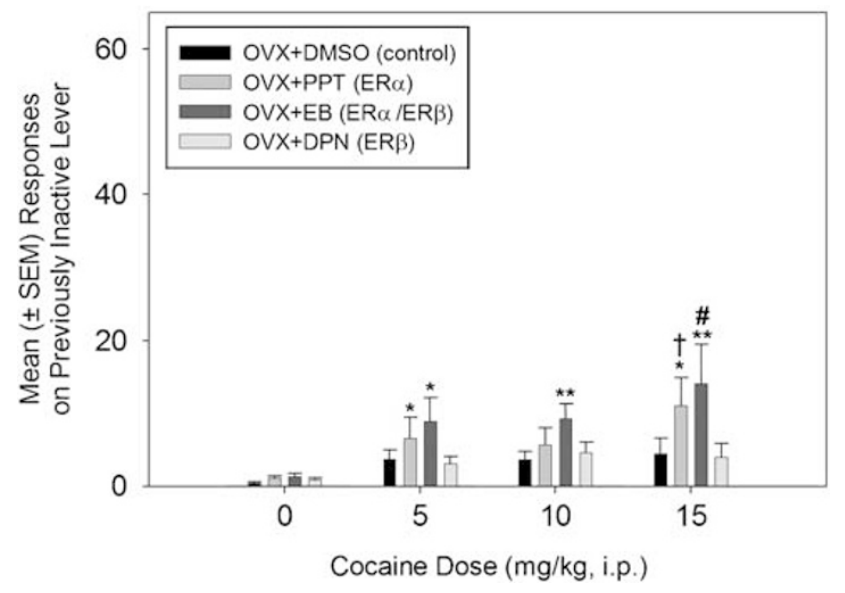

Figure 5 Reinstatement-inactive lever responding. Data points represent the mean $( \pm S E M)$ number of responses on the previously inactive lever. $* p<0.05$, ** $p<0.0$ I compared to $0 \mathrm{mg} / \mathrm{kg}$ dose within group, ${ }^{*} p<0.05 \mathrm{OVX}+\mathrm{EB}$ compared to OVX+DMSO and OVX+DPN groups, " $p<0.05 \mathrm{OVX}+\mathrm{PPT}$ compared to OVX+DMSO and OVX+ DPN groups. responding on these levers in the OVX $+\mathrm{EB}$ group. A two-way repeated measures ANOVA confirmed that lever responding increased as a function of cocaine priming dose $\left(\mathrm{F}_{3,79}=9.463, p<0.0001\right)$, but it also indicated that cocaine priming produced greater increases in active lever responding than inactive lever responding $\left(\mathrm{F}_{1,79}=20.642\right.$, $p<0.0001)$. Post hoc analysis confirmed that active lever responding was significantly greater than inactive lever responding after priming with the 10 and $15 \mathrm{mg} / \mathrm{kg}$ cocaine doses $(p<0.05)$. This indicates that the enhanced active lever responding in the OVX $+\mathrm{EB}$ group compared to OVX + DMSO (control) and OVX + PPT $(\mathrm{ER} \alpha)$ groups at these doses was specific for cocaine-seeking behavior, and it was not a result of generalized activity increases in the OVX + EB group.

\section{DISCUSSION}

\section{ER Activation and Active Lever Responding during Reinstatement}

In the present study, we examined the role of $\operatorname{ER} \alpha$ and $\operatorname{ER} \beta$ in estrogen's ability to enhance cocaine-induced reinstatement of cocaine-seeking behavior in female OVX rats. Consistent with previous work (Larson et al, 2005), we found that administration of $\mathrm{EB}$, a mixed $\mathrm{ER} \alpha / \mathrm{ER} \beta$ agonist, increased the magnitude of responding on the previously active (cocaine paired) lever compared to OVX + DMSO controls. We have expanded on this previous work to show that OVX rats treated with EB also reinstate cocaine-seeking behavior after lower priming doses of cocaine. That is, OVX $+\mathrm{EB}$ rats reinstated responding after a priming injection of $5 \mathrm{mg} / \mathrm{kg}$ cocaine, whereas a dose of $10 \mathrm{mg} / \mathrm{kg}$ cocaine was needed to produce significant reinstatement in the OVX + DMSO group. These findings indicate that estrogen can effectively promote the reinstatement of extinguished cocaine-seeking behavior in OVX female rats, even when cocaine self-administration has not been in effect for an extended period of time.

Similar to OVX $+\mathrm{EB}(\mathrm{ER} \alpha / \beta)$ rats, OVX rats treated with a $1.0 \mathrm{mg} / \mathrm{kg}$ dose of the $\operatorname{ER} \beta$-selective agonist DPN also reinstated cocaine seeking after lower priming doses of cocaine, and they showed more cocaine-seeking behavior during reinstatement compared to the OVX + DMSO controls. The magnitude of responding during reinstatement was also comparable between the OVX $+\mathrm{EB}$ and OVX + DPN groups. In contrast, rats treated with a $1.0 \mathrm{mg} / \mathrm{kg}$ dose of the ER $\alpha$-selective agonist PPT showed reinstatement of active lever responding that resembled that of the OVX + DMSO controls, indicating that the $\mathrm{ER} \alpha$ activation produced by this dose of PPT did not influence the amount of cocaine-seeking behavior. The dose of PPT and DPN that we used in this study $(1.0 \mathrm{mg} / \mathrm{kg})$ is biologically effective (Harris et al, 2002; Frasor et al, 2003; Lund et al, 2005) and selectively activates the $\operatorname{ER} \alpha$ and $\operatorname{ER} \beta$ subtypes, respectively (Lund et al, 2005). Furthermore, at the $1.0 \mathrm{mg} / \mathrm{kg}$ dose, both compounds can reach the brain within $30 \mathrm{~min}$ of peripheral administration (Harris et al, 2002; Lund et al, 2005), which corresponds to the timing of the treatment regimen used in this study. Overall, the results obtained during reinstatement testing strongly suggest that estrogen-mediated activation of $\operatorname{ER} \beta$, but not $\operatorname{ER} \alpha$, 
promotes the reinstatement of cocaine-seeking behavior in OVX female rats. Interestingly, it has been shown that tamoxifen, a partial agonist/antagonist at $\mathrm{ER} \alpha$, but pure antagonist at $\operatorname{ER} \beta$ (Barkhem et al, 1998), effectively reduced acquisition of cocaine self-administration in intact female rats (Lynch et al, 2001). Thus, activation of $\operatorname{ER} \beta$ may promote cocaine seeking across several phases of drug abuse, and $\operatorname{ER} \beta$ may be the basis for sex differences in drugtaking and drug-seeking behavior.

\section{ER Activation and Inactive Lever Responding during Reinstatement}

In the present study, although cocaine priming injections led to significantly more responding on the active compared to the inactive lever, cocaine priming injections were not without effect on inactive lever responding. Specifically, cocaine dose dependently increased inactive lever responding, and these increases were found to be significant in both the $\mathrm{OVX}+\mathrm{EB}(\mathrm{ER} \alpha / \beta)$ and $\mathrm{OVX}+\mathrm{PPT}(\mathrm{ER} \alpha)$ groups, but not in the OVX $+\mathrm{DPN}(\mathrm{ER} \beta)$ or $\mathrm{OVX}+\mathrm{DMSO}$ (control) groups. In self-administration paradigms, inactive lever responding is often considered to be a measure of general locomotor activity levels. Thus, in addition to promoting reinstatement of cocaine-seeking behavior, cocaine may have also caused increased locomotor activity in these animals. The finding that the $\mathrm{OVX}+\mathrm{EB}$ rats had greater inactive lever responding than OVX +DMSO rats is consistent with several studies that found that the locomotor activity produced by cocaine, at similar bolus doses that were used in the present study, was enhanced by estrogen treatment (eg, Sell et al, 2000, 2002; Perrotti et al, 2001; Chin et al, 2002). Interestingly, in contrast to what was found for active lever responding, the effect of $E B$ on inactive lever responding was also found in rats pretreated with PPT, but not those pretreated with DPN. These findings indicate that $\operatorname{ER} \alpha$ and $\operatorname{ER} \beta$ have differential roles in mediating estrogen's influence on locomotor activity and cocaine-seeking behavior, with $\mathrm{ER} \alpha$ exerting greater influence on locomotor activity and $\operatorname{ER} \beta$ exerting greater influence on cocaine-seeking behavior. It also suggests that estrogen's ability to enhance these effects may result from different underlying mechanisms and/or pathways in the brain.

\section{Possible Interpretations of the Results}

The relative differences found in active lever responding after cocaine priming injections suggest that $\operatorname{ER} \beta$ is important for promoting the vulnerability to reinstate cocaine-seeking behavior. One way that activation of $\operatorname{ER} \beta$ by either EB or DPN may have facilitated the reinstatement of cocaine-seeking behavior was by enhancing the rewarding effects or salience of the cocaine priming stimuli, resulting in a greater impact on subsequent cocaine-seeking behavior. As the magnitude of active lever responding during reinstatement has been used as a measure of an animal's motivation to obtain cocaine (De Wit and Stewart, 1981; Self et al, 1996), another possibility is that activation of $\operatorname{ER} \beta$ by $\mathrm{EB}$ or DPN served to enhance the incentivemotivational state of the rat. Some support for this idea comes from one study that used a progressive ratio schedule of reinforcement to assess motivation and found that under certain conditions EB could enhance responding for cocaine under this schedule (Lynch and Taylor, 2005). However, more research is needed to specifically examine the effects of estrogen and the role of $\operatorname{ER} \alpha$ and $\operatorname{ER} \beta$ on cocaineassociated motivational states.

As previously mentioned, one interpretation of inactive lever responding is that it reflects general locomotor activity levels. An alternative interpretation could be that inactive lever pressing reflected generalized or nonspecific responding. This nonspecific responding may indicate an error in the rat's ability to consistently recall which lever had previously been associated with cocaine, particularly when such correct recall did not result in cocaine reinforcement. In all groups, active lever pressing during reinstatement was greater than inactive lever pressing, suggesting that all groups of rats had retained the previously learned association between active lever pressing and delivery of the cocaine reward. However, it may be that activation of $\mathrm{ER} \beta$ with DPN resulted in a more consistent retention of this previously learned association than was produced by activation of ER $\alpha$ by PPT. Studies that have examined the role of ERs in estrogen's effects on learning and memory have suggested that the $\operatorname{ER} \beta$ subtype is important for learning and memory, including spatial learning (Rissman et al, 2002) and retention of spatial and inhibitory avoidance memory tasks (Rhodes and Frye, 2006). Conversely, activation of the $\mathrm{ER} \alpha$ subtype may inhibit learning (Fugger et al, 2000). Therefore, it is possible that differences in active and inactive lever responding between the OVX + $\mathrm{PPT}$ and OVX $+\mathrm{DPN}$ groups were due to differences in memory recall between the two groups. It may be that both groups were similarly motivated to seek cocaine, but the DPN-treated rats had a better ability than the PPT-treated rats to consistently recall which lever had previously been associated with the cocaine reward. However, if differences in $\operatorname{ER} \alpha$ and $\operatorname{ER} \beta$ activation led to differences in memory recall, we would have expected to find that treatment with PPT increased inactive lever responding after priming with both the 10 and $15 \mathrm{mg} / \mathrm{kg}$ doses of cocaine. It also might be expected that rats treated with $\mathrm{EB}(\mathrm{ER} \alpha / \beta)$ would have shown active and inactive lever responding at a level that was in-between that of OVX + PPT and OVX + DPN rats. In both respects, this was not the case. Unfortunately, the interpretations of the results are further complicated by the possibility of an interaction of $\operatorname{ER} \alpha$ and $\operatorname{ER} \beta$ effects on reward, motivation, and/or memory recall.

\section{Possible Brain Regions Involved in Estrogen Effects on Reinstatement}

Both $\mathrm{ER} \alpha$ and $\mathrm{ER} \beta$ are expressed in brain regions (eg, VTA, amygdala, and prefrontal cortex) that have been implicated in the reinstatement of drug-seeking induced by various stimuli, including stress, drugs, and cocaine-associated cues (See, 2002; Shalev et al, 2002; Shaham et al, 2003; AstonJones and Harris, 2004; Bossert et al, 2005; Weiss, 2005). Although the pathways underlying relapse induced by these stimuli differ, there is some overlap in brain regions such as the prefrontal cortex and nucleus accumbens (Self and Nestler, 1998; Kalivas and McFarland, 2003; Kalivas and Volkow, 2005). Given the results of the present study, it is 
unlikely that the effects of estrogen on reinstatement are a result of $\operatorname{ER} \beta$ activation in the amygdala, as this region has been implicated in reinstatement of drug-seeking behavior induced by cocaine-associated cues, but not for reinstatement elicited by priming injections of cocaine (McFarland and Kalivas, 2001; Kalivas and McFarland, 2003; Bossert et al, 2005). This idea is supported by recent studies in rats indicating that gonadal hormones (eg, estrogen) influence reinstatement induced by cocaine (Kippin et al, 2005; Larson et al, 2005), but not reinstatement elicited by exposure to cocaine-associated cues (Fuchs et al, 2005). Given that cocaine-induced reinstatement involves more direct activation of the mesolimbic pathway (ie, VTA to nucleus accumbens), it is likely that estrogen may be acting on receptors in these areas.

Both $\operatorname{ER} \beta$ mRNA and protein have been consistently found in the VTA (Shughrue et al, 1997; Shughrue and Merchenthaler, 2001; Creutz and Kritzer, 2002), and these receptors have been localized both on A10 dopamine neurons projecting to the striatum, as well as on nondopaminergic neurons within the VTA (Creutz and Kritzer, 2002). This, along with the apparent lack of ER $\alpha$ expression in this region, suggests that estrogen may promote the reinstatement of cocaine-seeking behavior by acting on $\operatorname{ER} \beta$ in the VTA. Estrogen activity at $\operatorname{ER} \beta$ in the VTA could potentially increase dopamine function by stimulating the activity of dopamine neurons, or conversely by reducing inhibitory influences on dopamine neurons. For example, activation of $\mathrm{GABA}_{\mathrm{B}}$ receptors in the VTA decreases cocaine self-administration (Brebner et al, 2000), and estrogen treatment reduces $\mathrm{GABA}_{\mathrm{B}}$-mediated $\mathrm{G}$-protein activation in the VTA (Febo and Segarra, 2004). Similarly, activation of $\operatorname{ER} \beta$ in the nucleus accumbens may also be involved in estrogen's effects on reinstatement. It has been suggested that $\mathrm{D}_{2}$-like dopamine receptors in the nucleus accumbens may be crucial for the reinstatement of drugseeking behavior (Self and Nestler, 1998), and $\operatorname{ER} \beta$, but not $\mathrm{ER} \alpha$, mediates estrogen-induced increases in $\mathrm{D}_{2}$ receptors in this region (Le Saux et al, 2006). Another possible site where estrogen may be acting to promote cocaine-induced reinstatement is the prefrontal cortex. The prefrontal cortex has been implicated in stress, cue, and drug-induced reinstatement (Bossert et al, 2005). Although no studies to date have specifically looked at $\operatorname{ER} \alpha$ and $\operatorname{ER} \beta$ localization in this specific region of the cortex, there is evidence that $\operatorname{ER} \beta$ may be the predominant ER subtype in various cortical regions (Shughrue et al, 1997; Laflamme et al, 1998). Thus, although more work is needed to understand the how estrogen activation of $\operatorname{ER} \beta$ may lead to increased cocaineseeking behavior, it is likely that these effects involve activation of $\operatorname{ER} \beta$ in regions of the brain associated with cocaine reward.

\section{Consideration of Study Limitations}

Although the results of the present study mainly indicate that $\operatorname{ER} \beta$ mediates estrogen's effects on the reinstatement of cocaine-seeking behavior, whereas $\mathrm{ER} \alpha$ may be more involved in the locomotor-activating effects of cocaine, there are a few limitations of the present study that should also be considered. First, only one dose $(1.0 \mathrm{mg} / \mathrm{kg})$ of the $\operatorname{ER} \alpha$ - and $\operatorname{ER} \beta$-selective agonists were examined in this study. It is unknown whether consistent results would have been found if higher or lower doses of the selective agonists were tested. For example, it is possible that higher doses of PPT $(E R \alpha)$ would have also facilitated the reinstatement of cocaine-seeking behavior. It is also possible that the increase in cocaine-seeking behavior seen with DPN $(\operatorname{ER} \beta)$ treatment was specific to the $1.0 \mathrm{mg} / \mathrm{kg}$ dose. Additionally, it is unclear whether coadministration of a $1.0 \mathrm{mg} / \mathrm{kg}$ dose of both PPT and DPN would have actually produced comparable effects to that found for rats treated with $\mathrm{EB}(\mathrm{ER} \alpha / \beta)$.

Another limitation of the present study was that the ER $\alpha$ selective agonist PPT had a far greater selectivity (300:1 $\operatorname{ER} \alpha: \operatorname{ER} \beta)$ than the $\operatorname{ER} \beta$-selective agonist DPN $(70: 1$ $\operatorname{ER} \beta: \operatorname{ER} \alpha)$. Therefore, while it is likely that the effects of PPT were selectively owing to its action at $\operatorname{ER} \alpha$, it is possible that the reported effects of DPN were not solely owing to $\operatorname{ER} \beta$ activation. For example, it has been shown that DPN can only stimulate $\operatorname{ER} \beta$ to about $45 \%$ of the activity of estradiol, after which it may also stimulate ER $\alpha$ (Meyers et al, 2001). Thus, it may be that the dose of DPN that we used in the present study may have produced activation of both $\operatorname{ER} \alpha$ and $\operatorname{ER} \beta$ subtypes. However, if treatment with DPN did activate a significant amount of $E R \alpha$, we would have expected to see an associated change in the vaginal cytology (ie, appearance of cornified epithelium), which we did not. Also, it has been reported by another group that daily administration of a $1.0 \mathrm{mg} / \mathrm{kg}$ dose of PPT increased uterine weight and upregulated progestin receptor immunoreactivity in the brain, whereas the same dose of DPN did not (Lund et al, 2005). Together, these findings suggest that treatment with PPT and DPN selectively activated the ER $\alpha$ and $\operatorname{ER} \beta$ subtypes, respectively. Even so, as our treatments were longer ( 9 days) than those used in previously mentioned study (4 days), the possibility that DPN activated both ER subtypes should be considered when interpreting the results of the present study.

A final limitation of the present study was the presence of soy- and alfalfa-derived phytoestrogens, specifically genestein, in the rat food. Although genestein has a greater affinity for the $\operatorname{ER} \beta$ than the $\operatorname{ER} \alpha$ subtype (Kuiper et al, 1997; Kostelac et al, 2003; Mueller et al, 2004; Zhao and Brinton, 2005; McCarty, 2006), it does have the potential to act as a full agonist at both these ER subtypes (Mueller et al, 2004; McCarty, 2006). However, as the vaginal cytology of the OVX + DMSO control rats did not show any evidence of vaginal cornification, we do not believe that exposure to phytoestrogens in the rat food led to any significant activation of the $\mathrm{ER} \alpha$ subtype. Nevertheless, we cannot exclude the possibility that phytoestrogen exposure in our rats led to some sort of activation of the $\operatorname{ER} \beta$ subtype. Phytoestrogen exposure may have also led to alterations in the number and/or affinity of $\operatorname{ER} \alpha$ or $\operatorname{ER} \beta$ in the brain. For example, genestein exposure can increase the rate at which bound $\operatorname{ER} \alpha$ and $\operatorname{ER} \beta$ subsequently bind to the estrogen response element, an effect that is slightly more pronounced for $\operatorname{ER} \beta$ than for $\operatorname{ER} \alpha$ (Kostelac et al, 2003). Thus, it is possible that increases in $\operatorname{ER} \beta$ activity relative to $\operatorname{ER} \alpha$ may have promoted more cocaine-seeking behavior in the OVX $+\mathrm{EB}(\mathrm{ER} \alpha / \mathrm{ER} \beta)$ and $\mathrm{OVX}+\mathrm{DPN}(\mathrm{ER} \beta)$ groups than would have been found if rats had been fed with a phytoestrogenfree diet. However, if increased activity of $\operatorname{ER} \beta$ resulting from genestein exposure did indeed underlie the increased 
cocaine-seeking behavior, it would be consistent with our conclusion that $\operatorname{ER} \beta$ plays an important role in estrogen's effect on the reinstatement of cocaine-seeking behavior.

\section{Summary and Conclusions}

In summary, the present study confirmed previous findings (Larson et al, 2005) indicating that $\mathrm{EB}(\mathrm{ER} \alpha / \beta)$ treatment increases the ability of cocaine priming to elicit reinstatement of cocaine-seeking behavior in OVX female rats. Activation of ER $\beta$ by the selective agonist DPN produced an enhancement of cocaine-induced reinstatement of active lever responding that was similar to $\mathrm{EB}$, whereas activation of $\mathrm{ER} \alpha$ by the selective agonist PPT had no effect on cocaine-seeking behavior relative to controls. In contrast, activation of ER $\alpha$ by PPT led to increases in inactive lever responding, suggesting that $\mathrm{ER} \alpha$ may be involved in EBrelated increases in locomotor activity after cocaine. Together, these findings indicate that activation of $\operatorname{ER} \beta$, but not $\mathrm{ER} \alpha$, plays in important role in estrogen's ability to promote the reinstatement of cocaine-seeking behavior. Whether this effect is due to alterations in reward, motivation, memory recall, or an interaction of these processes warrants further investigation. Overall, the results suggest that activation of ER $\beta$ may be important for the expression of sex differences in the vulnerability to relapse to cocaine.

\section{ACKNOWLEDGEMENTS}

This study was supported by NIDA Grants R01 DA03240 and K05 DA15267 (MEC). We thank Dr Jennifer Newman, Dr Jennifer Perry, and Justin Anker for their critical review of this manuscript, Danielle Johansson for her technical assistance, and Diana Freeman from Research Animal Resources at the University of Minnesota for her veterinary assistance.

\section{REFERENCES}

Aston-Jones G, Harris GC (2004). Brain substrates for increased drug seeking during protracted withdrawal. Neuropsychopharmacology 47: 167-179.

Avants SK, Margolin A, Kosten TR, Cooney NL (1995). Differences between responders and nonresponders to cocaine cues in the laboratory. Addict Behav 20: 215-224.

Barkhem T, Carlsson B, Nilsson Y, Enmark E, Gustafsson J-Å, Nilsson S (1998). Differential response of estrogen receptor $\alpha$ and estrogen receptor $\beta$ to partial estrogen agonists/antagonists. Molec Pharmacol 54: 105-112.

Becker JB (1999). Gender differences in dopaminergic function in striatum and nucleus accumbens. Pharmacol Biochem Behav 64: 803-812.

Bossert JM, Ghitza UE, Lu L, Epstein DH, Shaham Y (2005). Neurobiology of relapse to heroin and cocaine seeking: an update and clinical implications. Eur J Pharmacol 526: 36-50.

Brebner K, Phelan R, Roberts DC (2000). Intra-VTA baclofen attenuates cocaine self-administration on a progressive ratio schedule of reinforcement. Pharmacol Biochem Behav 66: 857-862.

Carroll ME, Lynch WJ, Roth ME, Morgan AD, Cosgrove KP (2004). Sex and estrogen influence drug abuse. Trends Pharmacol Sci 25: 273-279.
Chin J, Sternin O, Wu HBK, Burrell S, Lu D, Jenab S et al (2002). Endogenous gonadal hormones modulate behavioral and neurochemical responses to acute and chronic cocaine administration. Brain Res 945: 123-130.

Creutz LM, Kritzer MF (2002). Estrogen receptor- $\beta$ immunoreactivity in the midbrain of adult rats: regional, subregional, and cellular localization in the A10, A9, and A8 dopamine cell groups. J Comp Neurol 446: 288-300.

De Wit H, Stewart J (1981). Reinstatement of cocaine-reinforced responding in the rat. Psychopharmacology 75: 134-143.

Elman I, Karlsgodt KH, Gastfriend DR (2001). Gender differences in cocaine craving among non-treatment-seeking individuals with cocaine dependence. Am J Drug Alcohol Abuse 27: 193-202.

Febo M, Segarra AC (2004). Cocaine alters GABA(B)-mediated G-protein activation in the VTA of female rats: modulation by estrogen. Synapse 54: 30-36.

Festa ED, Quiñones-Jenab V (2004). Gonadal hormones provide the biological basis for sex differences in behavioral responses to cocaine. Horm Behav 46: 509-519.

Frasor J, Barnett DH, Danes JM, Hess R, Parlow AF, Katzenellenbogen BS (2003). Response-specific and ligand dose-dependent modulation of estrogen receptor (ER) $\alpha$ by $\operatorname{ER} \beta$ in the uterus. Endocrinology 144: 3159-3166.

Fuchs RA, Evans KA, Mehta RH, Case JM, See RE (2005). Influence of sex and estrous cyclicity on conditioned cue-induced reinstatement of cocaine-seeking behavior in rats. Psychopharmacology 179: 662-672.

Fugger HN, Foster TC, Gustafsson J- $\AA$, Rissman EF (2000). Novel effects of estradiol and estrogen receptor $\alpha$ and $\beta$ on cognitive function. Brain Res 883: 258-264.

Geary N, Asarian L, Korach KS, Pfaff DW, Ogawa S (2001). Deficits in E2-dependent control of feeding, weight gain, and cholecystokinin satiation in ER-alpha null mice. Endocrinology 142: 4751-4757.

Hall JM, Chang C, McDonnell DP (2000). Development of peptide antagonists that target estrogen receptor $\beta$-coactivator interactions. Molec Endocrinol 14: 2010-2023.

Harris HA, Katzenellenbogen JA, Katzenellenbogen BS (2002). Characterization of the biological roles of estrogen receptors, $\mathrm{ER} \alpha$ and $\mathrm{ER} \beta$, in estrogen target tissues in vivo through the use of an ER $\alpha$-selective ligand. Endrocrinology 143: 4172-4177.

Hewitt SC, Korach KS (2003). Oestrogen receptor knockout mice: roles for oestrogen receptors $\alpha$ and $\beta$ in reproductive tissues. Reproduction 125: 143-149.

$\mathrm{Hu}$ M, Crombag HS, Robinson TE, Becker JB (2004). Biological basis of sex differences in the propensity to self-administer cocaine. Neuropsychopharmacology 29: 81-85.

Imwalle DB, Gustafsson J- $\AA$, Rissman EF (2005). Lack of functional estrogen $\beta$ influences anxiety behavior and serotonin content in female mice. Physiol Behav 84: 157-163.

Jackson LR, Robinson TE, Becker JB (2006). Sex differences and hormonal influences on acquisition of cocaine self-administration in rats. Neuropsychopharmacology 31: 129-138.

Kalivas PW, McFarland K (2003). Brain circuitry and the reinstatement of cocaine-seeking behavior. Psychopharmacology 168: $44-56$.

Kalivas PW, Volkow ND (2005). The neural basis of addiction: a pathology of motivation and choice. Am J Psychiatry 162: 1403-1413.

Kippin TE, Fuchs RA, Mehta RH, Case JM, Parker MP, BimonteNelson HA et al (2005). Potentiation of cocaine-primed reinstatement of drug seeking in female rats during estrus. Psychopharmacology 182: 245-252.

Klein LC, Popke EJ, Grunberg NE (1997). Sex differences in effects of predictable and unpredictable footshock on fentanyl selfadministration in rats. Exp Clin Psychopharmacol 5: 99-106.

Kostelac D, Rechkemmer G, Briviba K (2003). Phytoestrogens modulate binding response of estrogen receptors $\alpha$ and $\beta$ to the estrogen response element. J Agric Food Chem 51: 7632-7635. 
Krezel W, Dupont S, Krust A, Chambon P, Chapman PF (2001). Increased anxiety and synaptic plasticity in estrogen $\beta$-deficient mice. Proc Natl Acad Sci USA 98: 12278-12282.

Kuiper GGJM, Carlsson B, Grandien K, Enmark E, Häggblad J, Nilsson $S$ et al (1997). Comparison of the ligand binding specificity and transcript tissue distribution of estrogen receptors $\alpha$ and $\beta$. Endocrinology 138: 863-870.

Kuppers E, Beyer C (1999). Expression of estrogen receptor- $\alpha$ and $\beta$ mRNA in the developing and adult mouse striatum. Neurosci Lett 276: 95-98.

Laflamme N, Nappi RE, Drolet G, Labrie C, Rivest S (1998). Expression and neuropeptidergic characterization of estrogen receptors $(\mathrm{ER} \alpha$ and $\mathrm{ER} \beta)$ throughout the rat brain: anatomical evidence of distinct roles of each subtype. J Neurobiol 36: $357-378$

Larson EB, Carroll ME (2005). Wheel running as a predictor of cocaine self-administration and reinstatement in female rats. Pharmacol Biochem Behav 82: 590-600.

Larson EB, Roth ME, Anker JJ, Carroll ME (2005). Effect of short- $v s$ long-term estrogen on reinstatement of cocaineseeking behavior in female rats. Pharmacol Biochem Behav 82: 98-108.

Le Saux M, Di Paolo T (2005). Chronic estrogenic drug treatment increases preporoenkephalin mRNA levels in rat striatum and nucleus accumbens. Psychoneuroendocrinology 30: 251-260.

Le Saux M, Morissette M, Di Paolo T (2006). ER $\beta$ mediates the estradiol increase of $\mathrm{D}_{2}$ receptors in rat striatum and nucleus accumbens. Neuropharmacology 50: 451-457.

Lund TD, Rovis T, Chung WCJ, Handa RJ (2005). Novel actions of estrogen receptor- $\beta$ on anxiety related behaviors. Endocrinology 146: 797-807.

Lynch WJ, Carroll ME (2000). Reinstatement of cocaine selfadministration in rats: sex differences. Psychopharmacology 148: 196-200.

Lynch WJ, Roth ME, Carroll ME (2002). Biological basis of sex differences in drug abuse: preclinical and clinical studies. Psychopharmacology 164: 121-137.

Lynch WJ, Roth ME, Mickelberg JL, Carroll ME (2001). Role of estrogen in the acquisition of intravenously self-administered cocaine in female rats. Pharmacol Biochem Behav 68: 641-646.

Lynch WJ, Taylor JR (2005). Decreased motivation following cocaine self-administration under extended access conditions: effects of sex and ovarian hormones. Neuropsychopharmacology 30: $927-935$.

McCarty MF (2006). Isoflavones made simple - Genistein's agonist activity for the beta-type estrogen receptor mediates their health benefits. Med Hypotheses 66: 1093-1114.

McEwen BS, Alves SE. (1999). Estrogen actions in the central nervous system. Endocr Rev 20: 279-307.

McFarland K, Kalivas PW (2001). The circuitry mediating cocaineinduced reinstatement of drug-seeking behavior. J Neurosci 21 : 8655-8663.

Meyers MJ, Sun J, Carlson KE, Marriner GA, Katzenellenbogen BS, Katzenellenbogen JA (2001). Estrogen receptor- $\beta$ potencyselective ligands: structure-activity relationship studies of diarylpropionitriles and their acetylene and polar analogues. J Med Chem 44: 4230-4251.

Mueller SO, Simon S, Chae K, Metzler M, Korach KS (2004). Phytoestrogens and their human metabolites show distinct agonistic and antagonistic properties on estrogen receptor $\alpha(\mathrm{ER} \alpha)$ and ER $\beta$ in human cells. Toxicol Sci 80: 14-25.

National Research Council (2003). Guide for the Care and Use of Mammals in Neuroscience and Behavioral Research. The National Academics: Washington.

Ogawa S, Chan J, Chester AE, Gustafsson J-Å, Korach KS, Pfaff DW (1999). Survival of reproductive behaviors in estrogen receptor beta gene-deficient (betaERKO) male and female mice. Proc Natl Acad Sci USA 96: 12887-12892.
Ogawa S, Chan J, Gustafsson J- ̊, Korach KS, Pfaff DW (2003). Estrogen increases locomotor activity in mice through estrogen receptor $\alpha$ : specificity for the type of activity. Endocrinology 144: 230-239.

Ogawa S, Eng V, Taylor J, Lubahn DB, Korach KS, Pfaff DW (1998). Roles of estrogen receptor-alpha gene expression in reproduction-related behaviors in female mice. Endocrinology 139: 5070-5081.

Perrotti LI, Russo SJ, Fletcher H, Chin J, Webb T, Jenab S et al (2001). Ovarian hormones modulate cocaine-induced locomotor and stereotypic activity. Ann NY Acad Sci 937: 202-216.

Perry JL, Morgan AD, Anker JJ, Dess NK (2006). Escalation of i.v. cocaine self-administration and reinstatement of cocaine-seeking behavior in rats bred for high and low saccharin intake. Psychopharmacology (in press).

Pfaff D, Keiner M (1973). Atlas of estradiol-concentrationg cells in the central nervous system the female rat. J Comp Neurol 151: 121-158.

Rhodes ME, Frye CA (2006). ERbeta-selective SERMs produce mnemonic-enhancing effects in the inhibitory avoidance and water maze tasks. Neurobiol Learn Mem 85: 183-191.

Rissman EF, Heck AL, Leonard JE, Shupnik MA, Gustafsson J (2002). Disruption of estrogen receptor $\beta$ gene impairs spatial learning in female mice. Proc Natl Acad Sci USA 99: 3996-4001.

Robbins SJ, Ehrman RN, Childress AR, O'Brien CP (1999). Comparing levels of cocaine cue reactivity in male and female outpatients. Drug Alcohol Depend 53: 223-230.

Roesch DM (2006). Effects of selective estrogen receptor agonists on food intake and body weight gain in rats. Physiol Behav 87: 39-44.

Roth ME, Cosgrove KP, Carroll ME (2004). Sex differences in the vulnerability to drug abuse: a review of preclinical studies. Neurosci Biobehav Rev 28: 533-546.

Roy EJ, Buyer DR, Licari VA (1990). Estradiol in the striatum: effects on behavior and dopamine receptors but no evidence for membrane steroid receptors. Brain Res Bull 52: 221-227.

See RE (2002). Neural substrates of conditioned-cued relapse to drug-seeking behavior. Pharmacol Biochem Behav 71: 517-529.

See RE, Grimm JW, Kruzich PJ, Rustay N (1999). The importance of a compound stimulus in conditioned drug-seeking behavior following one week of extinction from self-administered cocaine in rats. Drug Alcohol Depend 57: 41-49.

Self DW, Barnhart WJ, Lehman DA, Nestler EJ (1996). Opposite modulation of cocaine-seeking behavior by D1- and D2-like dopamine receptor agonists. Science 271: 1586-1589.

Self DW, Nestler EJ (1998). Relapse to drug-seeking: neural and molecular mechanisms. Drug Alcohol Depend 51: 49-60.

Sell SL, Scalzitti JM, Thomas ML, Cunningham KA (2000). Influence of ovarian hormones and estrous cycle on the behavioral response to cocaine in female rats. J Pharmacol Exp Ther 293: 879-886.

Sell SL, Thomas ML, Cunningham KA (2002). Influence of estrous cycle and estradiol on behavioral sensitization to cocaine in female rats. Drug Alcohol Depend 67: 281-290.

Shaham Y, Shalev U, Lu L, De Wit H, Stewart J (2003). The reinstatement model of drug relapse: history, methodology and major findings. Psychopharmacology 168: 3-20.

Shalev U, Grimm JW, Shaham Y (2002). Neurobiology of relapse to heroin and cocaine seeking: a review. Pharmacol Rev 54: 1-42.

Shelton KL, Beardsley PM (2005). Interaction of extinguished cocaine-conditioned stimuli and footshock on reinstatement in rats. Internat Soc Comp Psychol 18: 154-166.

Shughrue PJ, Lane MV, Merchenthaler I (1997). Comparative distribution of estrogen receptor- $\alpha$ and $-\beta$ mRNA in the rat central nervous system. J Compar Neurol 388: 507-525.

Shughrue PJ, Merchenthaler I (2001). Distribution of estrogen receptor beta immunoreactivity in the rat central nervous system. J Comp Neurol 436: 64-81. 
Stauffer SR, Coletta CJ, Tedesco R, Nishiguchi G, Carlson K, Sun J et al (2000). Pyrazole ligands: structure-affinity/activity relationships and estrogen receptor-alpha-selective agonists. J Med Chem 43: 4934-4947.

Sun J, Huang YR, Harrington WR, Sheng S, Katzenellenbogen JA, Katzenellenbogen BS (2005). Antagonists selective for estrogen receptor $\alpha$. Endocrinology 143: 941-947.

Sutton MA, Karanian DA, Self DW (2000). Factors that determine a propensity for cocaine-seeking behavior during abstinence in rats. Neuropsychopharmacology 22: 626-641.
Walf AA, Frye CA (2005). ER $\beta$-Selective estrogen modulators produce antianxiety behavior when administered systemically to ovariectomized rats. Neuropsychopharmacology 30: 1598-1609.

Weiss F (2005). Neurobiology of craving, conditioned reward and relapse. Curr Opin Pharmacol 5: 9-19.

Zhao L, Brinton RD (2005). Structure-based virtual screening for plant-based ERbeta-selective ligands as potential preventative therapy against age-related neurodegenerative diseases. $J$ Med Chem 48: 3463-3466. 